\title{
Energy Sustainability under the Framework of Telecoupling
}

\author{
Baling Fang ${ }^{\mathrm{a}}$, Yi Tan ${ }^{\mathrm{a}}$, Canbing Li ${ }^{\mathrm{a}, *}$, Yijia Cao ${ }^{\mathrm{a}}$, Jianguo Liu ${ }^{\mathrm{b}, *}$, Pia-Johanna \\ Schweizerc ${ }^{c}$, Haiqing Shi ${ }^{\mathrm{a}}$, Bin Zhou ${ }^{\mathrm{a}}$, Hao Chen ${ }^{\mathrm{d}}$, Zhuangli Hu ${ }^{\mathrm{a}}$ \\ ${ }^{a}$ College of Electrical and Information Engineering, Hunan University, Changsha, 410082, Hunan, China \\ ${ }^{\mathrm{b}}$ Center for Systems Integration, Michigan State University, East Lansing, 48823, MI, USA \\ ${ }^{c}$ Stuttgart Research Center for Interdisciplinary Risk and Innovation Studies, University of Stuttgart, Stuttgart, \\ 70174, BW, Germany \\ ${ }^{\mathrm{d}}$ College of Computer Science and Electronic Engineering, Hunan University, Changsha, 410082, Hunan, China
}

\begin{abstract}
Energy systems, which include energy production, conversion, transportation, distribution and utilization, are key infrastructures in modern society. Interactions among energy systems are generally studied under the framework of energy trade. Although such studies have generated important insights, there are limitations. Many distant interactions (e.g. the Fukushima nuclear crisis) are not in the form of trade, but affect energy sustainability. Even when distant interactions are related to energy trade, they are not systematically analyzed. Environmental impacts of trade are often not integrated with economic analysis of trade. In this paper, to identify and fill important knowledge gaps, we apply an integrated framework of telecoupling (socioeconomic and environmental interactions over distances). The framework of telecoupling, which is more comprehensive and cross-disciplinary than the energy trade framework, is a useful theoretical and methodological tool for analyzing distant interactions among coupled human and natural systems (including energy systems). Telecouplings widely exist in energy systems with various forms and link energy sustainability of different countries closely, so we proposed some methods for energy sustainability analysis under the framework of telecoupling. From the aspect of causes, a method is proposed to judge whether the telecoupling driven by economic factors is conducive to energy sustainability. From the aspect of effects, a method is proposed to assess whether an event is conducive to energy sustainability. The telecoupling framework presents opportunities for more profound and comprehensive understanding of energy sustainability.
\end{abstract}

\section{Keywords}

Climate change, Energy market, Energy sustainability, Environmental sustainability, Telecoupling

\section{Introduction}

Energy is the foundation of production and socioeconomic development, and all human activities are driven by energy $[1,2]$. Therefore, it is crucial to ensure energy

\footnotetext{
*To whom correspondence should be addressed. E-mail address: liuji@msu.edu(J. Liu), licanbing@qq.com (C. Li).
} 
sustainability [3, 4]. In terms of the world energy sustainability issues, the World Energy Council proposed the 'Energy Trilemma' - energy security, energy equity, and environmental sustainability [5], which is very useful for evaluating the energy sustainability of the region or country [6]. One challenge to achieve energy sustainability is the mismatch between the geographic distribution of energy and the demand around the world. To meet the energy demand, there are increasing distant interactions among places that generate and consume energy. Currently, the main approach to analyzing distant interactions among energy systems and their influences on energy sustainability is the energy trade conceptual framework [7-9], which is an effective tool to analyze economic effects. However, it is not complete and thorough. For example, the Fukushima nuclear crisis, which has nothing to do with energy trade, changed the energy production strategies around the world [10]. The distant interactions, which are critical for energy sustainability, are not adequately analyzed under the framework of energy trade, since they are not trade transactions or their impact go beyond socioeconomics. Thus, it is necessary to use a comprehensive framework to study energy-related distant interactions.

The award-winning framework of telecoupling is a good choice. Telecouplings are socioeconomic and environmental interactions among coupled human and natural systems over distances [11-15]. The framework of telecoupling includes five major interrelated components-systems, flows, agents, causes and effects. The movement of energy, which is activated by agents (decision-making entities that directly or indirectly influence telecouplings), may be part of important flows between coupled human and natural systems. Energy can also be part of the causes (reasons for why telecouplings appear and change) or effects (socioeconomic and environmental results of distant interactions) of telecouplings. So far the telecoupling framework has been applied to address a number of important issues such as conservation policy and food production [16], global land use [17], trade of goods and products (e.g., food, forest products, palm oil [18, 19]), global land grabbing and investment [20], species invasions [15], and payments for distant ecosystem services [21]. In this paper, we compare the framework of telecoupling with the framework of energy trade, apply the framework of telecoupling to several energy systems, and propose some methods for assessing energy sustainability under the framework of telecoupling. 


\section{Comparisons between the framework of energy trade and the framework of}

\section{telecoupling}

Through comparing the framework of telecoupling with the framework of energy trade, we find a number of important knowledge gaps. As shown in Table 1, the differences between two frameworks are listed as follows.

The systems in the framework of energy trade are the suppliers, traders, countries and users. The framework of telecoupling, besides persons and organizations involved in the transactions, brings in many non-energy components, such as air, water, animals, and plants.

The flows between systems analyzed by energy trade tools are limited to money, energy and information. Flows such as movement of persons, plants and animals are neglected. However, energy flows are always accompanied by these relevant flows. For example, invasive species may be transported through energy transportation. The Powder River Basin, Wyoming, is one of the most rapidly expanding areas of coal bed methane. Due to methane mining, there is a significantly greater proportion of nonnative species [22].

The agents of energy trade mainly include persons, companies and governments. Under the framework of telecoupling, other creatures, such as animals and plants, are also involved.

The causes of energy trade are limited to socioeconomic factors [23, 24]. Under the framework of telecoupling, environmental factors are also emphasized.

In the energy trade framework, effects mainly focus on the socioeconomic, including supply, demand, and price. Environmental impacts are often separately studied, underestimated or even ignored $[25,26]$. The influence of energy trade on socioeconomic, environmental and biological systems is generally simplified as trade costs and externality (an externality is the cost or benefit that affects a party who does not choose to incur that cost or benefit). For example, when a factory emits air pollutants, its neighbors suffer; in contrast, infrastructure (e.g. roads and power grid) built by a factory may benefits its neighbors [27]. The framework of telecoupling integrates socioeconomic and environmental effects in sending systems (e.g., origins of energy trade), receiving systems (e.g., destinations of the energy trade), and spillover systems (other systems that affect or are affected by interactions between 
sending and receiving systems, such as energy transport corridors) with comprehensive consideration on feedbacks. Furthermore, the telecoupling framework is methodologically and conceptually superior to the energy trade framework, because it is an interdisciplinary model that not only adequately depicts the complex flow of energy trade and consumption, but also offers a meta-theoretically sophisticated concept which integrates scientific analysis of different analytic levels and from various scientific disciplines, including political science, economics, biology, environmental science, and engineering.

As shown in Table 1 and based on the above comparisons, energy trade could be regarded as one form of energy-related telecoupling processes. The energy trade framework describes the socioeconomic components of telecoupling, with feedbacks almost ignored; focuses on fewer flows, agents, causes and effects; and involves fewer disciplines. By applying the telecoupling framework, many knowledge gaps left over by energy trade framework can be identified or even probably filled.

\section{A telecoupling example in energy systems}

Overview. There are many kinds of energy sources, such as oil, coal, natural gas, shale gas, solar, wind, and biomass. Different energy sources have different energy densities. Oil, coal and natural gas are examples of high-energy density resources. The energy density of some energy sources, such as biomass, is relatively low. Higher energy densities bring lower transportation cost ratios. Thus, agents are more likely to trade high-density energy sources between distant systems. Energy, the related energy utilization equipment, technology, and information are likely to be the flows in the telecoupling.

In addition, wind, solar, and some other energy sources must be consumed almost locally. Therefore, they usually cannot be the flows in telecoupling. However, in such cases, telecoupling still exists and the movements of equipment, technology and information are the flows. Among the cases, we choose the photovoltaic (PV) panel trade between China and the European Union (EU) to be detailedly introduced.

Telecoupling in solar energy. Solar energy is a fast-developing renewable energy that helps ensure energy sustainability. As a typical example of telecoupling, the PV panel trade between China and the EU involves every element of telecoupling including feedbacks. Chinese PV panel export to the EU is a typical example of 
telecoupling in new energy systems, as shown in Table 2. In this example, China is the sending system, and the EU is the receiving system. The agents related to the sending system include PV panel manufacturers (e.g., Yingli Solar, TSL), merchants (e.g., Liansheng Miao, Jifan Gao), and the Chinese government. The agents related to the receiving system include the governments in EU countries, dealers (e.g., Canadian Solar Inc.), PV panel contractors (e.g., Belectric, Greencells), local PV panel manufacturers (e.g., Solarworld, Solarcentury), and PV panel users.

The telecoupling causes are as follows. First, China has cheaper labor and lower penalty costs of environmental pollution compared with the EU. Second, the EU has developed a 20-20-20 strategy [28], which set three key objectives for 2020: a $20 \%$ reduction in the EU greenhouse gas emissions from 1990; an increase in the share of EU energy consumption produced from renewable resources to $20 \%$; and a $20 \%$ improvement in the EU's energy efficiency. Third, the PV panel incentive plans are set in some countries of the EU [29]. For example, Italian and Spanish incentive plans made it cheaper for citizens to install PV panels than to purchase electricity from power companies, which have resulted in a significant growth in PV panel installation [30]. In addition, advertisements and education on energy-saving and emission reduction make EU citizens more likely to install PV panels.

In this case, flows are the movement of PV panels from China and the money the EU paid to China. Different from petroleum trade, energy equipment movement is the flow. Chinese annual PV panel export was $15.3 \mathrm{GW}$ in capacity in 2011, which was 27.2\% higher than in 2010, and the EU imported 11.4 GW PV panels in capacity in 2011, which accounted for $74.7 \%$ of total Chinese export [31]. In 2011, the capacity of PV systems in EU was $51.716 \mathrm{GW}$ [32], and the PV generation was $44.8 \mathrm{TWh}$. China's export accounted for $22.04 \%$ of EU market.

There are complex effects including feedbacks in China and the EU. In 2011, the PV trade between China and the EU provided about 0.15 million jobs and $\$ 24.5$ billion GDP in China. These PV panels produce 98,700 GWh per year in EU, and cut down about 86 billion $\mathrm{kg}$ of $\mathrm{CO}_{2}$ and 329 million tons of coal. The feedback is complex. To produce PV panels for the EU, about 15.78 25.37 billion kWh of electricity were consumed, and about 11.78 18.97 million tons of carbon dioxide were emitted in China [33]. According to the average technological level of thermal power plants, 3,000 kWh of electricity would be generated and 2,620 kg of $\mathrm{CO} 2$ 
would be emitted by burning one ton of coal equivalent [34]. The fossil fuel market is influenced due to the reduction in fossil fuel consumption in EU. Therefore, China is more likely to purchase cheaper fossil fuels. In 2012, China accounted for 50.2\%, $11.7 \%, 4.3 \%$ of total coal, petroleum, natural gas consumption in the world, respectively [35]. The cheap fossil fuels are important to maintaining Chinese economic development. In June 2013, the EU announced an anti-dumping and antisubsidy investigation into the Chinese PV panel export. According to the temporal anti-dumping tax rate (11.8\%) from June 2013 to August 2013, the PV panel price increased from $0.66 \$ / \mathrm{W}$ to $0.78 \$ / \mathrm{W}$. Chinese PV products lost its price advantage, and at least $30 \%$ of Chinese PV companies closed or came to the verge of collapse. Accordingly, the Chinese government conducted a series of measures to respond, and other industries were influenced [36].

\section{How to apply the framework of telecoupling to assess energy sustainability}

Based on the analysis above, methods for assessing energy sustainability (e.g., reduction in energy consumption and increase in energy generation) are proposed in this section. Causes and effects of telecoupling are the entry points.

Through analyzing causes. Energy is not only a tradable commodity, but also an important input of any products. In this section, a new method for assessing energy sustainability is proposed through analyzing causes of telecoupling, using the production and trade of non-energy products as examples.

It depends on the consistency of energy and costs consumption whether the telecoupling caused by economic factors benefits energy sustainability. When higher energy consumption means higher costs for products and services, consumers will choose the option with less energy consumption out of the instinct of choosing cheaper products and services with similar performances. Therefore, consumers choose low-cost electric vehicles, which results in higher energy sustainability because of less energy consumption and carbon emissions. An example is shown as follows.

China imports vehicles from Japan, including hybrid vehicles and conventional vehicles. Japan is the sending system. China is the receiving system. Agents include the governments, car manufacturers (e.g., TOYOTA), dealers (e.g., Pang Da, China Grand Auto), and consumers. The flows are the vehicles, in which conventional 
vehicles account for a bigger proportion than hybrid vehicles. The cause of such flows is that conventional vehicles are cheaper. Due to China's tax policies and car manufacturers' pricing strategies, the prices of hybrid cars are significantly higher than conventional fuel vehicles, though hybrid vehicles consume about 60 percent or less fuel compared to traditional vehicles [37]. For example, a Toyota's third generation Prius hybrid vehicle in China comes with a starting price of RMB 229,800, equivalent to US $\$ 36,508$ as of 2012 [38], while a Toyota Corolla fuel vehicle in China, close to Toyota Prius hybrid vehicle in automotive performance, is between RMB 123,800 and 199,800, equivalent to US \$18,500-29,800 [39]. Therefore, with purchase cost and fuel cost taken into account, both of them need to travel through enough mileage or even go beyond the life-time mileage, for Prius to narrow the cost gap with Corolla. However, the scrap criterion of electric vehicles is not stipulated differently from conventional ones in the same category in the national regulation of China [40]. The obvious higher prices and the insufficient preferential policies of hybrid cars lead to the lack of purchases. Besides, considering the environmental and social costs including air pollution, internal combustion engine vehicles are still cheaper in term of the life-time than the hybrid gasoline-electric vehicles [41]. In this case, products and services with smaller costs have higher energy consumption. China's tax policies and car manufacturers' pricing strategies enlarged the imbalance between costs and energy consumption. Therefore, in the telecoupling, the conventional vehicles with higher energy consumption take a bigger proportion of flows than hybrid vehicles. If the hybrid vehicles become cheaper than conventional vehicles in the whole life cycle, more buyers would choose hybrid vehicles instead of conventional vehicles, as a result of less energy consumption and higher energy sustainability. According to the above analysis, it is necessary to keep the consistency of cost and energy consumption for the energy sustainability.

Carbon leakage is a typical example of the conflict among cost, energy consumption and greenhouse gas emissions. It occurs when there is an increase in carbon dioxide emissions in one country as a result of an emission reduction by a second country with a strict climate policy $[42,43]$. For example, Paltsev pointed out the carbon tax on iron and steel in Japan could result in an emission increase in China $[44,45]$. Carbon leakage is partly caused by inconsistency of cost and CO2 emissions. Some countries with carbon- or energy- intensive industries will suffer from increased 
production costs when $\mathrm{CO} 2$ emissions are reduced, resulting in a price advantage in carbon- or energy- intensive products of those countries without carbon limits [43].

Through analyzing effects. In this section, a method for assessing energy sustainability is proposed through analyzing effects of telecoupling. In the method, the effects of telecoupling are divided into several stages to explore the feedbacks in different time scales and among different systems. Through analyzing effects and feedbacks under the framework of telecoupling, more profound implications could be found. An example is shown as follows.

In March 11, 2011, a 9.0-magnitude earthquake occurred in the Pacific northeastern region of Japan, leading to a devastating tsunami. The tsunami resulted in continuous accidents in the Fukushima nuclear power plant, and leaked radioactive materials that impacted many countries [44-46]. The accidents caused a typical telecoupling whose effects are profound. We assess its influences on energy systems by applying the framework of telecoupling.

In this case of telecoupling in energy systems, the area at the Fukushima nuclear disaster is the sending system. Two major flows-radioactive substances and crisis information-resulted in multiple and complex receiving systems (countries that received the radioactive substances and crisis information).

In the case of the crisis information flow, the agents are the aid agencies, news media, transportation companies, environmental organizations, energy companies and governments. The spillover systems are other coupled human and natural systems, including people, sea, and air affected by interactions between sending and receiving systems.

Besides nuclear leakage, the crisis affected many countries' energy strategies [45-47]. Some countries, such as Germany, have decided to abandon nuclear plants. China decided to postpone constructing inland nuclear power plants. The United States continues to operate and expand nuclear power plants, but with more caution. Some countries like Sweden are reducing the output of nuclear power plants and paying more attention to renewable energy [47, 48]. The development of nuclear energy was also slowed down. Twelve reactors are closed permanently out of this event [49]. As a result, in 2011, there was a $2 \%$ decrease in the total capacity of nuclear generator in operation. These telecouplings described above can be illustrated as shown in Fig. 1. At the first stage, the disaster caused panic. Many countries cut 
down development plans for nuclear power plants, such as China, Germany, and Sweden, and some countries even shut down the existing nuclear power plants [46, 47]. In this stage, the restriction of nuclear power plants will boost the output of others power plants, especially fossil-fueled power plants, thus increasing the nonrenewable energy consumption and reduce energy sustainability. At the second stage, nuclear power equipment manufacturers would pay more attention to improving the safety of nuclear power systems, including the resistance to natural disasters, terrorist attacks, and power system fluctuations. Nuclear power enterprises would do publicity and restrain the public fear. Some governments would pay more attention to alternative energy, such as wind power and solar power. In this stage, the energy sustainability is roughly the same as the first stage. At the third stage, the safety of nuclear power systems would be enhanced, and public fear would gradually reduce. The costs of alternative energy might be higher than nuclear power, which is preferred but hindered because of safety concerns. Despite this, nuclear power would be acceptable for more and more people again. The nuclear power plants would benefit the energy sustainability, due to the increasing output by nuclear power plants and the decreasing consumption of fossil fuel. To sum up, the disaster would make nuclear power plants operated with a higher safety level from a long-term perspective.

According to the analysis above, if it was only assessed in a short time scale (for example only the first stage), or the feedbacks were ignored, only the severe negative effects on energy sustainability would be observed. In the long run, a different conclusion might be drawn after considering the interactions and feedbacks among public, nuclear power equipment makers, nuclear power enterprises, and governments, as shown in Fig. 2. Therefore, under the framework of telecoupling, both socioeconomic and environmental impacts are simultaneously taken into consideration, e.g., the decline of nuclear power generation in a short term and redevelopment of nuclear power plants with enhanced security level in a long term. Therefore, the conclusions are more comprehensive and practical. Long-term feedback can turn around the trend. From a long-term perspective, the nuclear leakage may increase the energy sustainability.

Implications of telecoupling for energy sustainability. Due to widespread telecouplings, one country's policy not only influences its energy (or environmental, climate) sustainability, but also causes complex changes in other countries. For 
instance, the EU vigorously promotes the development of renewable energy such as photovoltaic power, and thus international PV trade between China and the EU develops quickly. It is helpful for the EU's energy sustainability, but not conducive to Chinese environmental sustainability. On the other hand, when demand of EU reaches saturation, the abrupt reduction of order size could cause severe overcapacity in China's solar energy industry. For example, in 2012, the PV module manufacturers temporarily reduced its photovoltaic cell capacity from $2.4 \mathrm{GW}$ to $1.8 \mathrm{GW}$. Suntech Power Holdings Co., Ltd., world's largest producer of solar panels, had laid off over 5,500 jobs-over $40 \%$ of its workforce were affected [48]. In March 2013, Suntech announced a US $\$ 541$ million of bond payment default $[50,51]$. Because of the electric energy shortage in the eastern China, the government expects to develop abundant hydropower resources in western areas and transfer electricity to eastern regions through long-distance transmission. It benefits power supply in the eastern China, and greatly accelerates the hydropower station construction in the western regions. However, the hydropower station construction is likely to present negative effects on local and surrounding climate and environment, which influences climate and environmental sustainability [52-54].

The telecoupling reveals the complex interaction between the global energy and environmental sustainability. The influence of telecouplings should be taken into consideration seriously when advancing sustainable energy development. It could promote cooperation in the sustainable development of energy resources. We can also use it to analyze the impact of various events on energy sustainability, and analyze the distant interactions to enhance the energy complementarity.

\section{Conclusions}

The definition of energy sustainability is extended by applying the framework of telecoupling, and the influences of distant interactions on energy sustainability are analyzed. Many knowledge gaps can be identified and filled by adopting the framework of telecoupling, which makes the understanding of energy sustainability more profound and comprehensive. Furthermore, this paper's analytic results lead to the following recommendations:

I. The telecoupling exists widely in the energy systems, making the world energy systems a coupled entirety. In order to promote comprehensive energy sustainability, 
all countries need to work together. The telecoupling framework can be used to identify pivotal points for international collaboration, such as agreements on energy trade and international standards for energy generation and power efficiency. The ultimate goal of these policies is to call for a worldwide effort on energy sustainability for which the telecoupling framework provides the necessary analytic input.

II. The interrelationships among energy and environmental sustainability are complex. To promote sustainable development, the impacts of telecoupling should be fully considered in an increasingly interconnected world.

III. Through analyzing causes, a method is proposed to analyze whether the telecoupling driven by economic factors is conducive to energy sustainability.

IV. Through analyzing effects, a method is proposed to assess whether an event is conducive to energy sustainability.

V. Long-term feedbacks must be taken into account to fully understand the effects of telecoupling on energy sustainability.

\section{Acknowledgments}

This work is supported by the National Natural Science Fund of China under Grant 51137003, Hunan Strategic Industries Scientific and Technological Projects under Grant 2013GK4089, U.S. National Science Foundation, and Michigan AgBioResearch.

\section{References}

[1] Afgan NH, Gobaisi DA, Carvalho MG, Cumo M. Sustainable energy development. Renewable and Sustainable Energy Reviews. 1998;2:235-86.

[2] Hafele W. A global and long-range picture of energy developments. Science. 1980;209:174-82.

[3] Rosa EA, Diekmann A, Dietz T, Jaeger CC. Human Footprints on the Global Environment: Threats to Sustainability: The MIT Press; 2009.

[4] Cohen MJ, Brown HS, Vergragt P. Innovations in sustainable consumption: New economics, socio-technical transitions and social practices: Edward Elgar Publishing; 2013.

[5] Council WE. World Energy Trilemma. 2013; Accessed January, 2016. Available at https://www.worldenergy.org/work-programme/strategic-insight/assessment-of-energy-climatechange-policy/.

[6] Council WE. Energy Trilemma Index. 2013; Accessed January, 2016. Available at https://www.worldenergy.org/data/trilemma-index/.

[7] Farah PD, Cima E. Energy Trade and the WTO: Implications for Renewable Energy and the OPEC Cartel. Journal of International Economic Law. 2013;16:707-40.

[8] Tang X, Snowden S, Hook M. Analysis of energy embodied in the international trade of UK. Energy Policy. 2013;57:418-28.

[9] Cottier T, Nartova O, Rubini L, Bigdeli SZ, Matteotti S, Selivanova Y. Panel VII: Towards a WTO Framework Agreement on Trade in Energy. Society of International Economic Law (SIEL), Second Biennial Global Conference, University of Barcelona. 2010. 
[10] Kim Y, Kim M, Kim W. Effect of the Fukushima nuclear disaster on global public acceptance of nuclear energy. Energy Policy. 2013;61:822-8.

[11] Liu J, Dietz T, Carpenter SR, Alberti M, Folke C, Moran E, et al. Complexity of Coupled Human and Natural Systems. Science. 2007;317:1513-6.

[12] Liu J, Dietz T, Carpenter SR, Folke C, Alberti M, Redman CL, et al. Coupled Human and Natural Systems. AMBIO: A Journal of the Human Environment. 2007;36:639-49.

[13] Liu J, Mooney H, Hull V, Davis SJ, Gaskell J, Hertel T, et al. Sustainability. Systems integration for global sustainability. Science. 2015;347:1258832.

[14] Alberti M, Asbjornsen H, Baker LA, Brozovic N, Drinkwater LE, Drzyzga SA, et al. Research on Coupled Human and Natural Systems (CHANS): Approach, Challenges, and Strategies. Bulletin of the Ecological Society of America. 2011;92:218-28.

[15] Liu J, Hull V, Batistella M, DeFries R, Dietz T, Fu F, et al. Framing Sustainability in a Telecoupled World. Ecology and Society. 2013;18.

[16] Gasparri NI, de Waroux YlP. The coupling of South American soybean and cattle production frontiers: new challenges for conservation policy and land change science. Conservation Letters. 2014:n/a-n/a.

[17] Eakin H, DeFries R, Kerr S, Lambin EF, Liu JG, Marcotullio PJ, et al. Significance of Telecoupling for Exploration of Land-Use Change. Strungmann Forum Rep. 2014:141-61.

[18] Liu J. Forest Sustainability in China and Implications for a Telecoupled World. Asia \& the Pacific Policy Studies. 2014;1:230-50.

[19] Wicke B. Palm Oil as a Case Study of Distal Land Connections. Strungmann Forum Rep: The MIT Press; 2014.

[20] Liu J, Hull V, Moran E, Nagendra H, Swaffield SR, Turner BL. Applications of the Telecoupling Framework to Land-Change Science. Strungmann Forum Rep. 2014:119-39.

[21] Liu J, Yang W. Integrated assessments of payments for ecosystem services programs. Proc Natl Acad Sci U S A. 2013;110:16297-8.

[22] Bergquist E, Evangelista P, Stohlgren TJ, Alley N. Invasive species and coal bed methane development in the Powder River Basin, Wyoming. Environ Monit Assess. 2007;128:381-94.

[23] Bergasse E, Paczynski W, Dabrowski M, De Wulf L. The relationship between energy and socioeconomic development in the Southern and Eastern Mediterranean. CASE Network Reports. 2013.

[24] Tamborra M. Socio-economic tools for sustainability impact assessment. The Contribution of EU Research to Sustainable Development, European Commission, EUR. 2002;20437.

[25] Burgess PJ, Casado MR, Gavu J, Mead A, Cockerill T, Lord R, et al. A framework for reviewing the trade-offs between, renewable energy, food, feed and wood production at a local level. Renew Sust Energ Rev. 2012;16:129-42.

[26] Russ P, Ciscar JC, Saveyn B, Soria A, Szabo L, Van Ierland T, et al. Economic Assessment of Post-2012 Global Climate Policies-Analysis of Gas Greenhouse Gas Emission Reduction Scenarios with the POLES and GEM-E3 models. Institute for Prospective and Technological Studies, Joint Research Centre; 2009.

[27] Buchanan JM, Stubblebine WC. Externality. Economica. 1962;29:371-84.

[28] EUROPE 2020, A European strategy for smart, sustainable and inclusive growth. European Commission; 2010.

[29] Gros D, Roth F. The Europe 2020 Strategy: Can it maintain the EU's competitiveness in the world? Centre for European Ploicy Studies, CEPS Paperbacks. 2012.

[30] PABLO D, Pere M-A. Support for solar PV deployment in Spain: Some policy lessons. Renewable and Sustainable Energy Reviews. 2012.

[31] 2011 photovoltaic modules export data depth analysis (chart). 2012; Accessed May 2015. Available at http://guangfu.bjx.com.cn/news/20120702/370284.shtml.

[32] Association EPI. Global market outlook for photovoltaics until 2016.(2012). 2015.

[33] Clean Production of Solar PV in China. Accessed May 2015. Available at http://wenku.baidu.com/link?url=DihdDJiicVylk1T7d3aDvTA27SuLmE8-_lFHQLxYTTz9bcrtqqEIONL_5qrOHhYTjMWS2N5X8FQQBdpe3ie-x1_gzc-uytQGzEU8xSp04G.

[34] Zhuo Y, Yinghuai M. Thinking of energy-saving and emission reduction in electric power industry and low carbon economy. Journal of Environmental Management College of China. 2010;20:1-4.

[35] BP Statistical Review of World Energy June 2012. 2012; Accessed May 2015. Available at http://www.bp.com/content/dam/bp/pdf/Statistical-Review2012/statistical_review_of_world_energy_2012.pdf.

[36] France criticises China's anti-dumping probe into EU wine. 2013; Accessed May 2015. Available at http://www.bbc.co.uk/news/business-22778022. 
[37] Bennion K, Thornton M. Fuel Savings from Hybrid Electric Vehicles. National Renewable Energy Laboratory; 2009.

[38] Lee C. Sales of new Toyota Prius begin in China, prices start at 229800 yuan. 2012; Accessed May 2015. Available at http://autonews.gasgoo.com/china-news/sales-of-new-toyota-prius-beginin-china-prices-s-120225.shtml.

[39] Zheng A. New Toyota Corolla launched in China, priced between \$18,500-\$29,800. 2010; Accessed May 2015. Available at http://autonews.gasgoo.com/china-news/new-toyota-corollalaunched-in-china-priced-betwe-100928.shtml.

[40] MOFCOM Held the Special Press Conference on "Automobile Circulation Development Promoting Green \& Circular Consumption". 2013; Accessed May 2015. Available at http://www.fdi.gov.cn/1800000121_37_40949_0_7.html.

[41] Lipman TE, Delucchi MA. A retail and lifecycle cost analysis of hybrid electric vehicles. Transportation Research Part D: Transport and Environment. 2006;11:115-32.

[42] Intergovernmental Panel on Climate Change. 2010.

[43] Laihui X, Ying C. A review and analysis on carbon leakage. Advances in Climate Change Research. 2007;4:008.

[44] Paltsev SV. The Kyoto agreement: Regional and sectoral contributions to the carbon leakage. Department of Economics, University of Colorado, Working Paper 00-5.(available at http://www. colorado. edu/Economics/research/wp00-5. pdf); 2000.

[45] Lipscy PY, Kushida KE, Incerti T. The Fukushima disaster and Japan's nuclear plant vulnerability in comparative perspective. Environmental science \& technology. 2013;47:6082-8.

[46] Council WE. World energy perspective: nuclear energy one year after Fukushima. 2012; Accessed May 2015. Available at.

[47] Joskow PL, Parsons JE. The future of nuclear power after Fukushima. 2012.

[48] Beetz B. Suntech reduces PV cell capacity; announces layoffs. 2012; Accessed May 2015. Available at http://www.pv-magazine.com/news/details/beitrag/suntech-reduces-pv-cell-capacityannounces-layoffs_100008515/\#axzz2kz9WLGZM.

[49] IAEA. IAEA Annual Report for 2011. International Atomic Energy Agency; 2012.

[50] Wee S-L, Gopinath S. UPDATE 2-Solar pain hits China as Suntech unit nears insolvency. 2013; Accessed May 2015. Available at http://www.reuters.com/article/2013/03/20/china-suntechbankruptcy-idUSL3N0CC22I20130320.

[51] McDONALD J. Suntech announces default, search for financing. 2013; Accessed May 2015. Available at http://finance.yahoo.com/news/suntech-announces-default-search-financing142347010--finance.html.

[52] Tullos D. Assessing the influence of environmental impact assessments on science and policy: An analysis of the Three Gorges Project. Journal of Environmental Management. 2009;90, Supplement 3:S208-S23.

[53] Wu J, Huang J, Han X, Xie Z, Gao X. Three-Gorges Dam--Experiment in Habitat Fragmentation? SCIENCE-NEW YORK THEN WASHINGTON-. 2003:1239-.

[54] Morris C, Pehnt M. Energy Transition: The German Energiewende. 2012; Accessed May 2015. Available at http://energytransition.de/wp-content/themes/boell/pdf/en/German-EnergyTransition_en.pdf.

\section{Figure Legends}

Fig. 1. The effect of Fukushima nuclear plant crisis on energy systems. Nuclear power accident systems are parts of the sending system; the spillover systems include sea, air, marine creatures, and media. The countries and the public around the world are the main receiving systems. The disaster is the cause. The effects are complex and can be described at four stages. At the first stage, the disaster caused panic. Therefore, many countries had to cut down nuclear power plants plan, or even shut down the plants. At the second stage, nuclear power equipment manufacture firms would put more attention to enhance the safety of nuclear power systems. Nuclear power enterprises would enhance the publicity of the safety of nuclear power. Some governments would pay more attention to alternative energy, such as wind power and solar power. At the third stage, public fear would be gradually reduced. The safety of nuclear power systems would be enhanced. Note that nuclear power may always be cheaper than alternative energy. Therefore, the public would increase the acceptance of nuclear power. So, nuclear power would be developed again in the fourth stage. To sum up, the disaster would make the operating nuclear power plants with higher safety level from a long-time viewpoint. 
Fig. 2. The interactions and feedback among public, firms and governments. In the case of radioactive substance flow, countries around the world are the main receiving system; the accident nuclear power plants are parts of the sending system; the spillover systems include sea, air, and marine creatures that transmit the radioactive substance. At the first stage, public put their fear towards governments and nuclear power firms, and governments also press nuclear power firms. At the second stage, nuclear power firms enhance publicity to public and governments, and governments introduce the new decisions to public. At the third stage, public might feedback their acceptance of nuclear power, and governments would transfer the feedback to firms. 


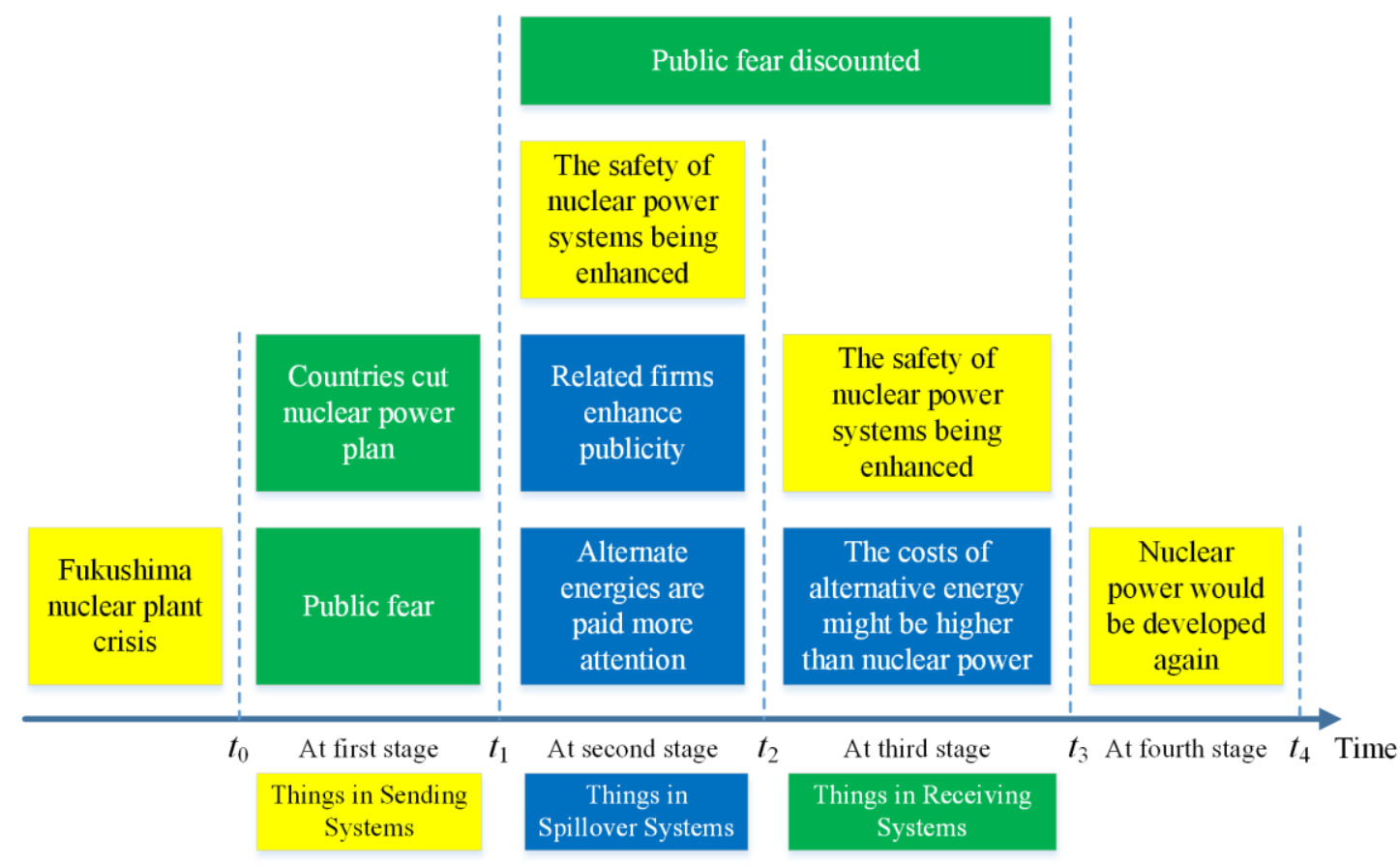




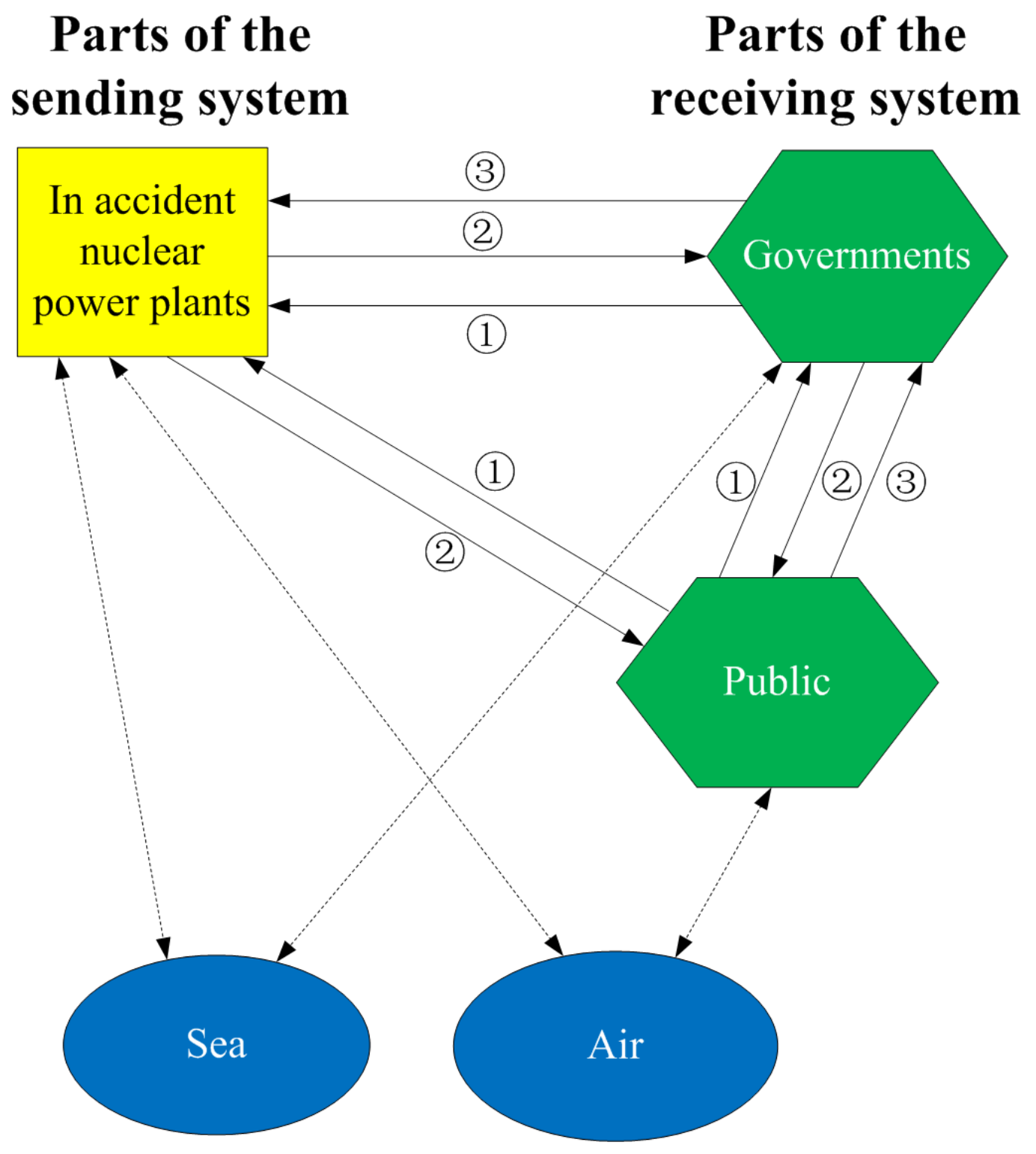

Parts of the spillover system 
Table 1. Comparative Analysis of Energy Sustainability Using Telecoupling Framework versus Energy Trade Framework

\begin{tabular}{|c|c|c|c|}
\hline & & Framework of energy trade & Framework of telecoupling \\
\hline Systems & $\begin{array}{l}\text { Sending and } \\
\text { Receiving Systems } \\
\text { Spillover Systems } \\
\text { (entities that are affected } \\
\text { by the distant interactions) }\end{array}$ & $\begin{array}{l}\text { Focus on transaction itself } \\
\text { transportation time and costs }\end{array}$ & $\begin{array}{l}\text { Sending systems including energy } \\
\text { suppliers and non-energy } \\
\text { components such as air, water, } \\
\text { people, and organisms. } \\
\text { Receiving systems-systems } \\
\text { including energy users and other } \\
\text { components (e.g., air, water, people). } \\
\text { Other systems beyond receiving and } \\
\text { sending systems, such as those along } \\
\text { the route of energy transportation }\end{array}$ \\
\hline Flows & & $\begin{array}{ll}\text { Energy and energy-related } \\
\text { equipment } \\
\text { - Energy related information } \\
\text { - Money }\end{array}$ & $\begin{array}{ll}\text { - } & \text { Energy and energy-related } \\
\text { equipment } \\
\text { - } \\
\text { - } \text { Mnergy related information } \\
\text { - Persons } \\
\text { - Organisms }\end{array}$ \\
\hline Agents & & $\begin{array}{ll} & \text { Persons } \\
\text { - } & \text { Companies } \\
\text { - } & \text { Governments }\end{array}$ & $\begin{array}{ll} & \text { Persons } \\
\text { - } & \text { Companies } \\
\text { - } & \text { Governments } \\
\text { - } & \text { Organisms } \\
\end{array}$ \\
\hline Causes & & $\begin{array}{ll} & \text { Socioeconomic factors } \\
\text { - } & \text { Environmental factors }\end{array}$ & $\begin{array}{ll} & \text { Socioeconomic factors } \\
\text { - } & \text { Environmental factors }\end{array}$ \\
\hline Effects & & $\begin{array}{l}\text { Most of the research focused on } \\
\text { socioeconomic effects, or } \\
\text { environmental effects } \\
\text { separately. } \\
\text { Do not attach importance to the } \\
\text { effects on other systems } \\
\text { Little consideration on feedback } \\
\text { The effects in spillover systems } \\
\text { are usually ignored. }\end{array}$ & $\begin{array}{l}\text { Socioeconomic and environmental } \\
\text { effects in sending, receiving and } \\
\text { spillover systems are considered } \\
\text { together. } \\
\text { Comprehensive consideration on } \\
\text { feedback can be taken into. }\end{array}$ \\
\hline Discipline & mainly involved & $\begin{array}{ll}- & \text { Energy } \\
\text { - } & \text { Economics }\end{array}$ & $\begin{array}{ll} & \text { Energy } \\
- & \text { Economics } \\
- & \text { Biology } \\
\text { - } & \text { Environmental science } \\
- & \text { Other disciplines } \\
\end{array}$ \\
\hline
\end{tabular}


Table 2. Telecoupling in solar energy

\begin{tabular}{|c|c|c|}
\hline & & Telecoupling in solar energy \\
\hline Systems & $\begin{array}{l}\text { Sending Systems } \\
\text { Receiving Systems } \\
\text { Spillover Systems }\end{array}$ & $\begin{array}{ll} & \text { China } \\
\text { - } & \text { European countries } \\
\text { - } & \text { Transport channel such as the Suez Canal, the Strait of Malacca }\end{array}$ \\
\hline Flows & & $\begin{array}{ll}- & \text { PV panels } \\
- & \text { Money } \\
- & \text { Fossil fuels in transportation } \\
\end{array}$ \\
\hline Agents & & $\begin{array}{l}\text { - Governments in EU countries, dealers, PV panel contractors, local } \\
\text { PV panel manufacturers, and PV panel users } \\
\text { - PV panel manufacturers } \\
\text { - Chinese governments }\end{array}$ \\
\hline Causes & & $\begin{array}{l}\text { - Government interest in renewable energy } \\
\text { - The EU 20-20-20 strategy and the PV panel incentive plans in EU } \\
\text { countries and districts } \\
\text { - Research and developing advanced PV products } \\
\text { - EU citizens preferring installing PV panels } \\
\text { Cheap labor and the low penalty cost of environmental pollution in } \\
\text { China }\end{array}$ \\
\hline Effects & $\begin{array}{l}\text { Economic } \\
\text { Environmental } \\
\text { Social }\end{array}$ & $\begin{array}{l}\text { - The increase in employment rate and taxes in China } \\
\text { - Substantial pollutants and greenhouse gas emissions in China } \\
\text { - Urban heat island effect reduction in EU } \\
\text { - Less } \mathrm{CO}_{2} \text { emissions } \\
\text { - Low carbon life }\end{array}$ \\
\hline
\end{tabular}

